\title{
Leader Levity: The Effects of a Leader's Humor Delivery on Followers' Positive Emotions and Creative Performance
}

\author{
Larry W. Hughes \\ University of Nebraska at Kearney
}

\begin{abstract}
In this paper, a leader's style of humor delivery is proposed to have an influence on followers' positive emotions (e.g., joy, contentment, pride in one's work), and subsequent creative performance. Extant literature is also presented in support of the proposition that humor delivery will have a positive effect on followers' creativity and innovation. Positive emotions are proposed to mediate the relationship between humor and creative performance.
\end{abstract}

\section{Introduction}

We are a wise guy society and there is evidence of it all around us. Political hopefuls and candidates drop one-liners during speeches, press conferences and debates; CEOs offer amusing anecdotes to illustrate why a new strategic direction must be implemented; professors employ humor to enhance student learning, and psychologists and medical doctors use humor to build patients' hope and resiliency. Professionals attend humor workshops in order to learn how to use this elusive social lubricant and humor experts are invited to organizations for the same purpose.

One explanation of the increasing use of this phenomenon is that humor is used on all of the above examples to reduce the social distance created in power relationships. People employed as such are leaders in any society and there is a natural social distance between them and their followers. There are even those who suggest that having a sense of humor at work, or perhaps employing humor techniques, will boost productivity. Previous research and commentary in the organization sciences has considered the role of workplace humor (cf. Cooper, 2005; Duncan, Smeltzer, \& Leap, 1990; Romero \& Cruthirds, 2006; Vinton, 1989). However, there is limited extant literature discussing the role of humor in the social influence process of leadership (for a review, see Martin, 2007). In this paper, I will offer explanation of why a leader's use of humor is important to key workplace outcomes such as positive emotions and creative performance, and caution against an inappropriate use.

\section{Literature Review and Propositions}

The propositions presented in this paper depict a leader's influence on followers' creative performance via humor, as mediated by positive emotions. In the following sections, a case is presented in support of a leader's use of humor and how this will influence follower creative performance, as well as a follower's 
positive emotions. A literature review of the constructs is followed by implications for management. A theoretical model, presented below, depicts the propositions advanced in this paper.

Figure 1. Theoretical model of leader humor style and outcomes.

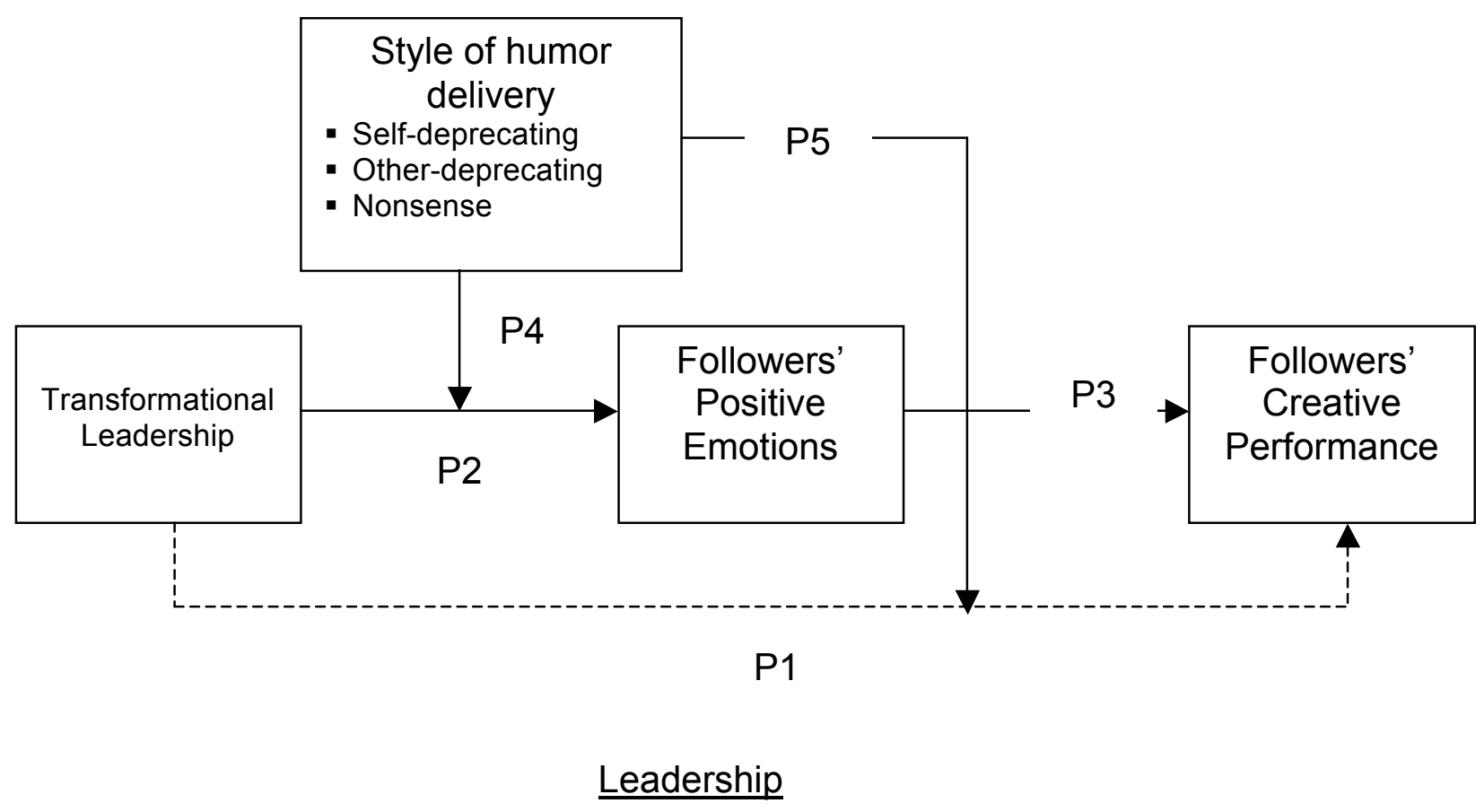

Leadership has enjoyed more than a century of research in the social sciences and has been considered from a wide breadth of theoretical perspectives. These perspectives range from seminal and more current consideration of trait theories (Mann, 1959; Stogdill, 1948; Judge, Bono, llies, \& Gerhardt, 2002), behaviors (Hemphill \& Coons, 1957; Likert, 1961), situation and context (Fiedler, 1964; Hersey \& Blanchard, 1969), motivation (House \& Mitchell, 1974) and exchange theories (Dansereau, Graen, \& Haga, 1975; Graen \& Uhl-Bien, 1995) and new genre theories (see Reichard \& Avolio, 2005, and Yammarino, Dionne, Uk Chun, \& Dansereau, 2005). The new genre theories comprise those theories that have been developed and tested since the early 1980's, primarily transactional and transformational leadership (Bass \& Avolio, 1994). Although a discussion of all existing theories of leadership is well beyond the scope of this paper, a summary of the new genre leadership theories is appropriate to the propositions, advanced herein, that leadership and a leader's style of humor delivery will interact to influence follower outcomes.

In the context of this work, leadership is proposed to exist orthogonally along two dimensions: quality and style. Along the quality dimension, leadership can be considered effective (good) or ineffective (bad). What effectiveness means is determined by the outcomes desired. For example, an effective leader in terms of 
worker performance can motivate followers thus compelling them to complete a series of tasks to an optimal outcome (i.e., units produced). Conversely, an ineffective leader is not able to motivate followers to produce the desired quantity of output. Similarly, an effective leader who can compel employees to feel happier in their work is converse to the ineffective leader who angers employees. Therefore, the outcome a leader attempts to elicit from followers determines precisely how effective is defined.

Style of leadership refers to the category in which fall leader behaviors, and follower attributions of these behaviors. The new-genre theories, introduced previously, are dominated by research on transactional and transformational leadership (Bass \& Avolio, 1994; Bass \& Riggio, 2006). A transactional leader's orientation is reward- and goal-oriented and thus compels followers to act in desirable manner motivates via follower self-interest by offering rewards and meting out punishment. Conversely, transformational leaders use a personalized style by which they espouse their values, effectively communicate their visions, inspire follower innovation, and connect individually with followers.

Neither style is completely appropriate or inappropriate. Oftentimes the situation dictates which style a leader should employ. Although leaders demonstrate a tendency to behave primarily in a transactional or transformational manner, Bass and Avolio (1994), suggest that leaders can employ varying degrees of both styles as the situation may warrant. While the two styles are unique, each is effective as appropriate. Furthermore, leaders may employ elements of either style as necessary.

There are thousands of published research studies of the outcomes of leadership. Within the literature on transformational and transactional leadership alone, scholars have studied the effects of leadership across industries and gender on financial performance, worker performance, and cognitive, affective and behavioral outcomes (cf. Dundum, Lowe, \& Avolio, 2002; Lowe, Kroeck, \& Sivasubramaniam, 1996). The linkage between leadership and both innovation and follower emotions has been well established in the extant literature, as presented above. While the financial performance outcome of the leadershiphumor linkage has been explored (Avolio, Howell, \& Sosik, 1999) this article reviews the potential for other important outcomes. Therefore, in this paper, leadership is proposed to influence the various outcomes outlined herein, and is offered as evidence that the phenomenon exists and that the leader's humor style will interact with leadership to elicit these effects. The Full Range Model of leadership has been presented, which contains both transformational and transactional leadership styles. However, from this point the propositions advanced are done so from the perspective of transformational leadership.

\section{Creative Performance}

Creativity and individual creative processes are not new topics and have been

Copyright (c) 2009 Institute of Behavioral and Applied Management. All Rights Reserved. 
studied extensively in the behavioral sciences. However, little work has been done within the context of leader-follower relationships. This is unexpected because innovation and creativity have been offered as important performance outcomes for organizations (Lei \& Slocum, 2005). The following quotation sums this notion quite well: "In a knowledge driven, global business environment, the concept of creativity seems primed to enjoy the same attention as TQM" (Jaussi \& Dionne, 2003, p. 475).

In recent years, there has been a growing body of work about the importance of innovation and creativity as an outcome of the leader-follower relationship. Examples of this work include a synthesis of leadership research on creativity published since 1990 (Mumford, Scott, Gaddis, \& Strange, 2002). Additionally, there has been study of the effects of unconventional leader behavior on follower creative performance at the individual and group levels finding that unconventional leader behavior was a construct distinct from, and explained variance in group cohesion beyond that of, transformational leadership (Jaussi \& Dionne, 2003).

Other relevant work includes the discovery that creativity ratings correlated with effective, leader-follower exchange relationships (Tierney, Farmer, \& Graen, 1999), and a study of leader problem construction and contribution to follower efficacy beliefs resulting in follower creativity (Redmond, Mumford, \& Teach, 1993). Additionally, Avolio and colleagues (Sosik, Avolio, \& Kahai, 1998; Sosik, Kahai, \& Avolio, 1999) studied the positive effects of transformational leadership on group fluency and flexibility, and the mediating role of flow and anonymity between transformational leadership and creativity.

Here, it is proposed that leaders can influence their followers' performance on creative tasks. Specifically, leaders with a transformational style are thought to have a more positive influence on follower outcomes than other types of leadership, such as the transactional style. Therefore, the following proposition is advanced:

Proposition 1: Transformational leadership behavior will have a direct, positive relationship with followers' creative performance.

\section{Positive Emotions}

Emotions are a conscious or unconscious multi-component response tendency that evolve and manifest over relatively short periods of time (Fredrickson, 2003). They are comprised of the personal meaning of antecedent events, or the person-environment relationship (Lazarus, 1991). Emotions have an object, or signify some thing (e.g., occurrence), and involve an appraisal process that triggers response tendencies such as subjective experiences, physiological changes and facial expressions (e.g., the Duchenne smile; Fredrickson, 1998). 
In recent years, Fredrickson (1998, 2003; Fredrickson \& Joiner, 2002) has positioned positive emotions in the emerging field of positive psychology. The broaden-and-build theory suggests that individuals' thought-action repertoires can be constructed in order to strengthen personal resources (i.e., physical, intellectual, psychological, and social; Fredrickson, 2003). Outcomes of the development of positive emotions are "upward spirals toward optimal individual and organizational functioning" (Fredrickson, 2003, pp. 163). This is partly accomplished through a broadening of the cognitive context (Isen, 1987).

Fredrickson (2003) cites evidence why positive emotions researchers should not observe the traditional notion that emotions are associated with urges to act in particular ways, called specific action tendencies (i.e., a fight-or-flight response to fear). Specific actions are appropriate for the discussion of negative emotions and responses, but they have not been linked to positive emotions such as joy and contentment, which tend to be more like feeling states than specific, physiological responses to stimuli (e.g., fear; Fredrickson, 2003). Instead, Fredrickson suggests that distinct theories should be allowed for different emotions or for different subsets of emotions (e.g., positive and negative emotions) rather than relying on a single theory to explain all emotions.

In response to this observed need, Fredrickson $(1998,2003)$ has offered a theory of thought-action tendencies in response to positive emotions. Negative emotions are local feeling states that narrow the response repertoire to specific actions, while positive emotions have been hypothesized as global feeling states that broaden response repertoires. Rather than assuming specificity of response, Fredrickson proposed a discussion of the relative breadth of the momentary thought-action repertoire.

Fredrickson's (1998) broaden-and-build theory describes the broadening of people's thought-action repertoires that enables them to explore novel approaches to thought and action, or the broadening of attention and cognition. The build component refers to the person's ability to develop various personal resources (e.g., intellectual, psychological, physical and social). The hypotheses that reciprocal relationships between positive emotions, broadened cognitions and positive meaning trigger upward spirals toward emotional well-being have been empirically supported (Fredrickson \& Joiner, 2002; Fredrickson \& Branigan, 2005).

Fredrickson (1998) has offered forth several categories of positive emotions, including joy, interest, contentment and love that contain other similar emotions. Love has been proposed as a fusion of the other three positive emotion categories. Fredrickson (2003) also discusses pride, following personal achievement, as a positive emotion. Each category contains emotions of similar type as the category title. For example, the positive emotion category of joy contains the specific emotions of joy, cheerfulness and exhilaration, among others. Empirical evidence supports that positive emotions characterize human 
flourishing (Fredrickson \& Losada, 2005)

Leadership style, particularly transformational leadership, was constructed on the notion that leaders develop the potential of followers (Bass \& Avolio, 1994). Positive emotions enlarge the cognitive context and therefore produce thought patterns that are both flexible and creative (Fredrickson \& Joiner, 2002; Isen, 1987). Personal resources built through broadening are proposed to be both enduring and durable (Fredrickson, 2003). Wofford and Goodwin (1994) proposed that leaders who cognitively emphasize transformational behaviors include more content regarding followers' individuality and creativity than those leaders who cognitively emphasize transactional leadership behaviors. Proposition 2 is therefore advanced:

Proposition 2: Transformational leadership behavior will have a direct, positive relationship with followers' positive emotions.

\section{Effects of Positive Emotions on Creative Performance}

Ashkanasy (2004) presented theoretical and empirical support for the nexus of emotions and performance. Previously, Ekvall (1996) found that members who were emotionally involved in an organization's operations and goals were also more creative; those who were more playful and who worked in climates in which humor and light mood were fostered were also more innovative.

As discussed previously, positive emotions enlarge the cognitive context and therefore produce patterns of thought that are flexible and creative (Fredrickson, 2003; Fredrickson \& Joiner, 2002). This occurs through Fredrickson's (1998) broaden-and-build theory, which was presented above. In other words, positive emotions broaden one's "thought-action repertoires" in order to explore novel approaches to thought and action. Positive emotions build one's ability to develop various personal resources, such as intellect, psychology, physical and social. Empirical support for this assertion has been offered by Isen (1993) who suggested that positive affect tends to promote the exploration and enjoyment of new ideas and possibilities.

Positive affect has also been found to promote creativity in problem solving and negotiation exercises (Carnevale \& Isen, 1986), and speed and efficiency in decision making (Isen \& Means, 1983). Isen (1993) suggested that positive affect tends to promote the exploration and enjoyment of new ideas and possibilities, as well as new ways of looking at things.

Cognitive organization, or schematic structure, is the way information is related to other information (Isen, 1993). Furthermore, not only is the way information is cognitively organized important, but so too is the content of what is being organized (Dozois, 2002). Isen and Daubman (1984) conducted four studies and found that positive affect influenced creative performance on word association 
projects, but interpreted their results in relation to the influence of positive affect on cognitive organization. This lent support to Fredrickson's (1998) later work on the thought-action repertoire hypothesis. Isen, Johnson, Mertz, \& Robinson (1985) investigated the influence of positive affect with their results indicating that it may facilitate performance in creative problem solving and thus provided support for the effects of positive feelings on cognitive organization. In light of the preceding evidence, I advance the following proposition:

Proposition 3: Followers' positive emotions will have a direct, positive relationship with followers' creative performance.

\section{Humor}

...humor can coldly cut or warmly bind together ...The quest for a single, universal definition of humor is reminiscent of the search for personality and intelligence, neither of which has definitions accepted by all. -MacHovec (1988, p. ix)

Humor as a construct has enjoyed the attention of hundreds of books, countless articles in academic and popular publications and in thousands of research studies. Even scholars in the organization sciences (e.g., Avolio et al., 1999; Cooper, 2005) have considered the topic, although not to the extent that it has in other disciplines such as communication, psychology and anthropology.

Scholars have repeatedly attempted to develop briefer taxonomies of humor, but to little avail. Many definitions of humor are tautological in that they use humor outcomes (e.g., laughter) as an explanatory mechanism of the humor construct (Roeckelein, 2002). Here, humor is more easily defined according to the theoretical lens through which it is viewed, which will lead to a discussion of styles of humor use.

\section{Theories of Humor}

Eysenck's (1942; Nias, 1981) typology of affective (psychoanalytical), cognitive (incongruity) and conative (social-behavioral) theories is the most succinct psychological model offered to date and has been reflected throughout the twentieth century in the work of other noted humor scholars who have elaborated upon this model, but retained its basic features (Lefcourt \& Martin, 1986; Raskin, 1985).

The first two theories, affective/arousal and cognitive/incongruity, are useful to explain why jokes are funny, but it is conative/superiority theory that most aptly explains humor. Superiority theory is considered, by some theorists, to be the sole explanatory theoretical basis for humor because all humor has a superiority element to it, even if generated in fun or in a so called harmless fashion, and a dissection of any joke, riddle or pun reveals a butt of the story (Gruner, 1997). 
Therefore, the focus of this study is on the conative leg of the Eysenck humor model. A presentation of the superiority theory of humor will follow brief descriptions of the arousal and incongruity theories.

Arousal theories. Arousal, or affect, theories are those in which humor induced laughter reduces built-up tension. Early conceptualizations include Joubert's physio-psychological theory of laughter as being pleasure mixed with pain; Descartes's discussion of both the physiological and psychological aspects of affect-based, derisive humor, and McDougall's relief theory (Roeckelein, 2002). Modern discussions include Freud's (1963) theory of humor as defense mechanism against unpleasant emotion; Berlyne's theory of a relationship between physiological arousal and subjective pleasure, and Apter's reversal theory, which is concerned with meta-motivational states that, basically, define a person's outlook as serious or one of humor (Lefcourt, 2001).

Incongruity theories. While arousal theories focus on why things are funny, incongruity theories tell us what it is about the structure of jokes that makes them funny. The basis of incongruity is that things that one finds funny must be somewhat unexpected, ambiguous, illogical or inappropriate (Meyer, 1997). Known also as bisociation, cognitive elements are salient when two normally disparate and incompatible frames of reference -- ideals or situations -- are brought together in a surprising or unexpected manner (Koestler, 1964). This dual perception is what makes a good joke funny. Suls (1983) further argued that incongruity requires resolution, which is critical for eliciting a humorous response. An example is the punch line of a joke that makes sense on the basis of information received earlier in the joke. Early thinkers who discussed the cognitive theories were Cicero, Locke, Kant and Schopenhauer (Roeckelein, 2002).

Superiority theories. The fountainhead of most humor theories depends on either a sense of our own superiority or on a sense of the inferiority of others. The twocomponent approach to superiority theory was originally suggested by Hobbes who said, in Leviathan, that laughter occurs when "a sudden glory [arises] from some sudden conception of some eminency in ourselves; by comparison with the infirmity of others, or with our own formerly" (Berleyne, 1969, pp. 801). Plato and Aristotle each observed the superiority nature of humor albeit as threatening (Roeckelein, 2002).

Superiority humor theories hold that actors derive pleasure from another's misfortune without experiencing cognitive dissonance or fear of social censure. Most humor techniques, or specific uses of humor, fall under this category. Examples include absurdity, cynicism, facetiousness, imitation, insults, invective, irony, parody, ridicule, sarcasm and satire (Berlyne, 1969; Berger, 1992).

Humor scholar Charles Gruner (1997) argues that all humor is evoked for the purpose of establishing superiority and that other theories are only loosely to be 
considered theories of humor subsumed under that of superiority theory. Because analyses of humor and jokes reveal a target, regardless of the joker's intent, humor is offered here as typically employed to poke fun at someone (including oneself). Therefore, the superiority theory of humor will be the framework upon which this paper is based. In light of this, two ways in which humor can be delivered to an audience are via self- or other-derogation. Both styles fall within the superiority perspective of humor in that all humor is created at the expense of either oneself or someone else.

Humor is thought to result from a sense of superiority derived from the derogation of another person or of ourselves in our former naiveté. But it is not always employed in order to elevate oneself in relation to a disliked target as evidenced in the use of putdown humor in temporary groups, which had a socializing effect provided that certain rules of its use were observed (Terrion, \& Ashforth, 2002).

Conversely, it has been suggested that self-directed ridicule is useful in communicating to followers that leaders or managers have a sense of humor and can laugh at themselves (Vinton (1989). In this model, the self- deprecating humor condition is posited to be the most effective because it does not invoke superiority over other people whereas familiar-other-deprecating humor specifies a familiar target, other than the leader, who is put down or ridiculed. Self-directed humor makes a powerful statement to followers, and thus enables those over whom they have authority to see that leaders are accessible rather than remote, capable of adopting detached perspectives of them and are models for others to do the same (Kahn, 1989).

\section{Styles of Humor Delivery}

Because humor is situational and unique to each audience member (Roeckelein, 2002) different styles of delivering a humorous message will have differential effects on listeners. The three styles of humor delivery offered in this paper are (1) a self-deprecating style in which leaders pokes fun at themselves; (2) a familiar-other-deprecating (putdown) style in which leaders poke fun at a focal actors in a social situation, and (3) a nonsense style in which the butt of the joke, if any, is not the leader or focal actors and is purely incongruous.

\section{Effects of Humor on Positive Emotions}

Humor itself is not an emotion (McGhee, 1979). However, Moore and Isen (1990) suggested that affect is manipulated by humor. Although the impact is seldom profound it has been found to reliably alter emotion states. Isen (1987) addressed the problem of asymmetry between positive and negative emotions suggested that these effects may result from different cognitive contexts generated by the dichotomy. 
Humor elicits positive affective responses such as exhilaration, joy and cheerfulness (Fredrickson, 1998; Ruch, 1993). It has been found that laughter occurs after conditions of heightened tension or arousal when, concurrently, there is a judgment that the situation is safe or inconsequential (Nias, 1981). Fredrickson (2003) said that the act of laughing results in higher contentment, an emotion she has identified as positive (Fredrickson, 1998).

Researchers have found, using the Multidimensional Sense of Humor Scale (MSHS), that participants with higher sense of humor scores suffer lower levels of depression (Thorsen \& Powell 1994). Others found positive correlations between a high sense of humor and optimism (Thorsen, Powell, SarmanySchuller, \& Hampes, 1997). Participants with lower sense of humor were more pessimistic. High sense of humor was also negatively correlated with negative self-esteem. Kohler and Ruch (1996) found positive correlations between high MSHS scores and cheerfulness, and negative correlations between high MSHS scores and seriousness and bad mood.

In other research, greater levels of humor were associated with a more positive self-concept (i.e., higher self-esteem) and greater positive affect in response to both positive and negative life events (Martin, Kuiper, Olinger, \& Dance, 1993). Nias (1981) cited research in which cartoons presented to participants under conditions of high moderate and low anxiety and anger produced an emotional state incompatible with anger expression. Baron and Ball (1974) angered participants and then exposed them to comic humor. Subsequent scores on a mood measure indicated that feelings of anger decreased for those participants in the humor condition. Therefore, humor is not only an effective coping mechanism (Lefcourt, 2001), but may also enhance the enjoyment of positive life experiences. This moderating effect of humor has been established in leadership research (Avolio et al., 1999).

Proposition 4: Style of humor delivery will have a moderating influence on the relationship between leadership and positive emotions.

Proposition 4a: A leader's self-deprecating style of humor delivery will have more positive effect on followers' positive emotions than other styles.

Proposition 4b: A leader's other-deprecating style of humor delivery will have more negative effect on followers' positive emotions than other styles.

Proposition 4c: A leader's use of a nonsense style of humor delivery will have a more(less) positive effect on followers' positive emotions than an otherdeprecating (self-deprecating) style of humor delivery.

\section{The Effects of Humor on Creativity}

It is hypothesized here that followers' positive emotions has a partial mediating 
effect on the relationship between a leader's style of humor delivery and follower's creative performance. Humke and Schaefer (1996) found, using the MSHS, a direct linkage between a greater sense of humor among mental health workers and higher levels of creativity on a drawing completion test. Previously, Ruch (1993) hypothesized that humor has a positive effect on exhilaration and joy (positive emotions) that, in turn, have an effect on creativity. Furthermore, researchers have found evidence of mediation in that students who were more anxious performed better on multiple-choice examinations after exposure to written humor (Smith, Ascough, Ettinger, \& Nelson, 1971). Isen, Daubman, and Nowicki (1987) conducted four experiments indicating that positive affect, induced by comedy, improved participant performance on two creativity tasks. In light of this evidence, a leader who evokes positive emotions in followers by employing an appropriate style of humor delivery can expect followers to be more creative.

Proposition 5: Style of humor delivery will have a moderating influence on the relationship between leadership and creative performance.

Proposition 5a: A leader's self-deprecating style of humor delivery will have more positive effect on followers' creative performance than other styles.

Proposition 5b: A leader's other-deprecating style of humor delivery will have more negative effect on followers' creative performance than other styles of delivery.

Proposition 5c: A leader's use of a nonsense style of humor delivery will have a more(less) positive effect on followers' creative performance than an otherdeprecating (self-deprecating) style of humor delivery.

\section{Implications for Management}

Work in itself does not have to be laborious, joyless, brutally repetitious, isolated in its performance, and, in general, deformative of human beings. -O'Hare (1992)

Scholars have offered humor as an essential and important part of organizational life. Conceptual articles have proposed the value of humor as ingratiatory behavior (Cooper, 2005), in improving work group performance (Duncan et al., 1990), and as a tool for organizational change Kahn (1989). A leader's use of humor in delivering a message can also be an effective persuasive device (Geuens \& De Pelsmacker, 2002) and has the power to bridge distances between managers and employees so that they might identify with each other and view the organization through the same lens (Fox \& Amichai-Hamburger, 2001).

Humor is useful in that it facilitates communication by allowing one to say things otherwise left unsaid. Message content is emphasized by heightening a truth to a 
level that it will not only be seen as funny, but also so that its stark reality is revealed. This revelation occurs because, conceptually, humor enables organization members to create psychological distance between them and difficult issues. The paradox is that our ability to psychologically adopt the detached perspective that humor offers depends partly on our having already assumed sufficient detachment from a situation so as to perceive its humor (Kahn, 1989). Examples in the organization include the gallows humor of workers on the front-line of an otherwise emotional issue (e.g., paramedics).

Furthermore, a growing body of empirical work has revealed positive effects of humor in organizations. Avolio et al. (1999) studied the moderating influence of humor on leadership and organizational outcomes in the banking and insurance industries (e.g., financial performance). Vinton (1989) found that humor alleviated status differentials and workplace tension between organization members. Humor was also found to enhance employee perceptions of manager effectiveness (Rizzo, Booth-Butterfield, \& Wanzer, 1999).

As discussed previously, innovation and creativity have been offered as important performance outcomes for organizations (Lei \& Slocum, 2005). Jaussi and Dionne (2003) conducted research on the effectiveness of a leader's unorthodox behavior on follower innovation. Mumford and colleagues (2002) prepared a synthesis of current research on creativity. Sosik et al. $(1998,1999)$ studied the relationships between transformational leadership and creativity. Additional work on the elicitation of creativity via leadership has been done in the context of advanced information technology (Kahai, Sosik, \& Avolio, 2003).

Here, we propose that a leader's use of humor can be seen as a positive influence and not merely as clowning around. By using an appropriate display of humor a leader can elicit positive outcomes, such as positive emotion states and creativity and innovativeness, all of which have been empirically linked. In an age during which innovation contributes to an organization's competitive advantage these are useful and unique propositions.

\section{Conclusion}

In this paper the goal was to provide evidence for the need to seriously consider the study of humor and leadership and to help eliminate the doggerel and puerile attributed to its study. Leaders are key role models in leader-follower relationships. Furthermore, they can lead with a sense of humor that emphasizes precisely what they are saying. Here, I proposed positive effects of a leader's delivery of humor on follower positive emotions, such as joy, contentment and interest. Positive emotions were offered as an important mediator in the relationship between the interaction of leadership and style of humor delivery, and also the more distal outcome of followers' creative performance. 


\section{References}

Ashkanasy, N. (2004). Emotion and performance. Human Performance, 17, 137144.

Avolio, B. J., Howell, J. M., \& Sosik, J. J. (1999). A funny thing happened on the way to the bottom line: Humor as a moderator of leadership style effects. Academy of Management Journal, 42, 219-227.

Baron, R. A., \& Ball, R. L. (1974). The aggression-inhibiting influence of nonhostile humor. Journal of Experimental Social Psychology, 10, 23-33.

Bass, B. M., \& Avolio, B. J. (1994). Transformational leadership: Improving organizational effectiveness. Thousand Oaks, CA: Sage.

Bass, B., \& Riggio, R. (2006). Transformational leadership, Mahwah, NJ: Erlbaum.

Berger, A. (1992). An anatomy of humor. New Brunswick, NJ: Transaction Publishers.

Berlyne, D. (1969). Laughter, humor, play. In G. Lindzey, \& E. Aronson (Eds.), Handbook of Social Psychology: Vol. 3 (pp. 795-852). Reading, MA: AddisonWesley.

Carnevale, P. J. D., \& Isen, A. M. (1986). The influence of positive affect and visual access on the discovery of integrative solutions. Organizational Behavior and Human Decision Processes, 37, 1-12.

Cooper, C. D. (2005). Just joking around? Employee humor expression as an ingratiatory behavior. Academy of Management Review, 30(4), 765-776

Dansereau, F., Graen, G. B., \& Haga, W. (1975). A vertical dyad linkage approach to leadership in formal organizations. Organizational Behavior and Human Performance, 13, 46-78.

Dozois, D. J. A. (2002). Cognitive organization of self-schematic content in nondysphoric, mildly dysphoric, and moderately-severely dysphoric individuals. Cognitive Therapy and Research, 26, 417-429.

Dumdum, U.R., Lowe, K.B., \& Avolio, B.J. (2002). A meta-analysis of transformational and transactional leadership correlates of effectiveness and satisfaction: An update and extension. In Avolio, B.J., \& Yammarino, F. (Eds.), Transformational and charismatic leadership: The road ahead (pp. 3566). New York: JAI Press. 
Duncan, W. J., Smeltzer, L. R., \& Leap, T. L. (1990). Humor and work: Applications of joking behavior to management. Journal of Management, 16, 255-278.

Ekvall, G. (1996). Organizational climate for creativity and innovation. European Journal of Work and Organizational Psychology, 5, 105-123.

Eysenck, H. J. (1942). The appreciation of humor: An experimental and theoretical study. British Journal of Psychology, 32, 295-309.

Fiedler, F. E. (1964). A contingency model of leadership effectiveness. In L. Berkowitz (Ed.), Advances in experimental social psychology (Vol. 1, pp. 149190). New York: Academic Press.

Fox, S., \& Amichai-Hamburger, Y. (2001). The power of emotional appeals in promoting organizational change programs. Academy of Management Executive, 15, 84-94.

Fredrickson, B. L. (1998). What good are positive emotions? Review of General Psychology, 2, 300-319.

Fredrickson, B. L. (2003). Positive emotions and upward spirals in organizations. In K.S. Cameron, J.E. Dutton, \& R.E. Quinn, (Eds.), Positive organizational scholarship (pp. 163-175). San Francisco, CA: Berrett-Koehler.

Fredrickson, B. L., \& Branigan, C. (2005). Positive emotions broaden the scope of attention and thought-action repertoires. Cognition and Emotion, 19(3), 313-332.

Fredrickson, B. L., \& Joiner, T. (2002). Research report: Positive emotions trigger upward spirals toward emotional well-being. Psychological Science, 13, 172175.

Fredrickson, B. L., \& Losada, M. F. (2005). Positive affect and the complex dynamics of human flourishing. American Psychologist, 60(7), 678-686.

Freud, S. (1963). Jokes and their relation to the unconscious (J. Strachey, Ed. \& Trans.). New York: Norton. (Original work published 1905)

Geuens, M., \& De Pelsmacker, P. (2002). Role of humor in the persuasion of individuals varying in need for cognition. Advances in Consumer Research, $29,50-56$.

Graen, G. B., \& Uhl-Bien, M. (1995). Relationship-based approach to leadership: Development of a leader-member exchange (LMX) theory of leadership over 25 years: Applying a multi-level, multi-domain perspective. The Leadership 
Quarterly, 6(2), 219-247.

Gruner, C. R. (1997). The game of humor: A comprehensive theory of why we laugh. New Brunswick, NJ: Transaction Publishers.

Hemphill, J. K., \& Coons, A. E. (1957). Development of the Leader Behavior Description Questionnaire. In R. M. Stogdill, \& A. . Coons (Eds.), Leader behavior: Its description and measurement (Research Monograph No. 88). Columbus, OH: Ohio State University, Bureau of Business Research.

Hersey, P., \& Blanchard, K. H. (1969). Life-cycle theory of leadership. Training and Development Journal, 23, 26-34.

House, R. J., \& Mitchell, R. R. (1974). A path-goal theory of leadership. Journal of Contemporary Business, 3, 81-97.

Humke, C., \& Schaefer, C. (1996). Sense of humor and creativity. Perceptual and Motor Skills, 82, 544-546.

Isen, A. M. (1987). Positive affect, cognitive processes and social behavior. Advances in Experimental Social Psychology, 20, 203-253.

Isen, A. M. (1993). Positive affect and decision making. In M. Lewis, \& J. M. Haviland (Eds.), Handbook of Emotions (pp. 261-277). New York, NY: Guilford Press.

Isen, A. M., \& Daubman, K. A. (1984). The influence of affect on categorization. Journal of Personality and Social Psychology, 47, 1206-1217.

Isen, A. M., \& Means, B. (1983). The influence of positive affect on decisionmaking strategy. Social Cognition, 2, 18-31.

Isen, A. M., Daubman, K. A., \& Nowicki, G. P. (1987). Positive affect facilitates creative problem solving. Journal of Personality and Social Psychology, 52, $1122-1131$.

Isen, A. M., Johnson, M. M., Mertz, E., \& Robinson, G. F. (1985). The influence of positive affect on the unusualness of word associations. Journal of Personality and Social Psychology, 48, 1413-1426.

Jaussi, D. S., \& Dionne, S. D. (2003). Leading for creativity: The role of unconventional leader behavior. The Leadership Quarterly, 14, 475-498.

Judge, T. A., Bono, J. E., Ilies, R., \& Gerhardt, M. W. (2002). Personality and leadership: A qualitative and quantitative review. Journal of Applied Psychology, 87, 765-780. 
Kahai, S. S., Sosik, J. J., \& Avolio, B. J. (2003). Effects of leadership style, anonymity, and rewards on creativity-relevant processes and outcomes in an electronic meeting system context. The Leadership Quarterly, 14, 499-524.

Kahn, W. (1989). Toward a sense of organizational humor: Implications for organizational diagnosis. Journal of Applied Behavioral Science, 25, 45-63.

Koestler, A. (1964). The act of creation. New York: Macmillan.

Kohler, G., \& Ruch, W. (1996). Sources of variance in current sense of humor inventories: How much substance, how much method variance? Humor: International Journal of Humor Research, 9, 363-397.

Lazarus, R. S. (1991). Emotion and adaptation. New York, NY: Oxford.

Lefcourt, H. M. (2001). Humor: The psychology of living buoyantly. New York, NY: Kluwer Academic/Plenum Publishers.

Lefcourt, H. M., \& Martin, R. A. (1986). Humor and life stress: Antidote to adversity. New York, NY: Springer-Verlag.

Lei, D., \& Slocum, J. W. (2005). Strategic and organizational requirements for competitive advantage. Academy of Management Executive, 19, 31-45.

Likert, R. (1961). New patterns of management. New York: McGraw-Hill.

Lowe, K. B., Kroeck, K. G., \& Sivasubramaniam, N. (1996). Effectiveness correlates of transformational and transactional leadership: A meta-analytic review of the MLQ literature. The Leadership Quarterly, 7, 385-425.

MacHovec, F.J. (1988). Humor: Theory, history, applications. Springfield, IL: Thomas.

Mann, R. D. (1959). A review of the relationship between personality and performance in small groups. Psychological Bulletin, 56, 241-270.

Martin, R. A. (2007). The psychology of humor: An integrative approach. Burlington, MA: Elsevier.

Martin, R. A., Kuiper, N. A., Olinger, L. J., \& Dance, K. A. (1993). Humor, coping with stress, self-concept, and psychological well-being. Humor: International Journal of Humor Research, 6, 89-104.

McGhee, P. E. (1979). Humor: Its origin and development. San Francisco, CA: Freeman. 
Meyer, J. C. (1997). Humor in member narratives: Uniting and dividing at work. Western Journal of Communication, 61, 188-209.

Moore, B., \& Isen, A. (1990). Affect and social behavior. In B., Moore, \& A. Isen, (Eds.), Affect and social behavior (pp. 1-21). Cambridge, UK: Cambridge University Press.

Mumford, M. D., Scott, G. M., Gaddis, B., \& Strange, J. (2002). Leading creative people: Orchestrating expertise and relationships. Leadership Quarterly, 13, 705-750.

Nais, D. K. B. (1981). Humor and personality. In R. Lynn (Ed.), Dimensions of personality (pp. 287-313). Oxford, U.K.: Pergamon.

O'Hare, P. (1992). Work, irony and contemplative formation. Religious Education, $87,28-44$.

Raskin, V. (1985). Semantic mechanisms of humor. Boston, MA: Reidel Publishing.

Redmond, M. R. Mumford, M. D., \& Teach, R. J. (1993). Putting creativity to work: Leader influences on subordinate creativity. Organizational Behavior and Human Decision Processes, 55, 120-151.

Reichard, R. J., \& Avolio, B. J. (2005). Where are we? The status of leadership intervention research: A meta-analytic summary. In W.L. Gardner, B.J. Avolio, \& F.O. Walumbwa, (Eds.), Authentic leadership theory and practice: Origins, effects and development: Vol. 3. Monographs in leadership and management (pp. 203-226). Amsterdam: Elsevier JAI.

Rizzo, B. J., Booth-Butterfield, M., \& Wanzer. M. B. (1999). Individual differences in managers' use of humor: Subordinate perceptions of managers' humor. Communication Research Reports, 16(4), 360-369.

Roeckelein, J. E. (2002). The psychology of humor: A reference guide and annotated bibliography. Westport, CT: Greenwood Press.

Romero, E. J., \& Cruthirds, K. W. (2006). The use of humor in the workplace. Academy of Management Perspectives, 20(2), 58-69.

Ruch, W. (1993). Exhilaration and humor. In M. Lewis, \& J. M. Haviland (Eds.), Handbook of emotions (pp. 605-616). New York: Guilford Press.

Smith, R. E., Ascough, J. C., Ettinger, R. F., \& Nelson, D. A. (1971). Humor, anxiety and task performance. Journal of Personality and Social Psychology, 
19, 243-246.

Sosik, J. J., Avolio, B. J., \& Kahai, S. S. (1998). Inspiring group creativity: Comparing anonymous and identified electronic brainstorming. Small Group Research, 29, 3-31.

Sosik, J. J., Kahai, S. S., \& Avolio, B. J. (1999). Leadership style, anonymity, and creativity in group decision support systems: The mediating role of optimal flow. Journal of Creative Behavior. 33, 227-257.

Stogdill, R. M. (1948). Personal factors associated with leadership: A survey of the literature. Journal of Psychology, 25, 35-71.

Suls, J. (1983). Cognitive processes in humor appreciation. In P.E. McGhee \& J.H. Goldstein (Eds.), Handbook of humor research: Basic issues (pp. 39-57). New York: Springer-Verlag.

Terrion, J. \& Ashforth, B. E. (2002). From 'l' to 'we': The role of putdown humor and identity in the development of a temporary group. Human Relations, 55 , 55-88.

Thorsen, J., \& Powell, F. (1994). Depression and sense of humor. Psychological Reports, 75(3, Pt. 2), 1473-1474.

Thorsen, J., Powell, F., Sarmany-Schuller, I., \& Hampes, W. (1997). Psychological health and sense of humor, Journal of Clinical Psychology, 53, 605-619.

Tierney, P., Farmer, S. M., \& Graen, G. B. (1999). An examination of leadership and employee creativity: The relevance of traits and relationships. Personnel Psychology, 52, 591-620.

Vinton, K. L. (1989). Humor in the workplace: It is more than telling jokes. Small Group Behavior, 20, 151-166.

Wofford, J. C., \& Goodwin, V. L. (1994). A cognitive interpretation of transactional and transformational leadership theories. The Leadership Quarterly, 5, 161186.

Yammarino, F., Dionne, S., Uk Chun, J., \& Dansereau, F. (2005). Leadership and levels of analysis: A state-of-the-science review. The Leadership Quarterly, 16, 879-919. 